\title{
Records of regalecid fishes in Argentine waters
}

\author{
ANA E. RUIZ ${ }^{1} \&$ ATILA E. GOSZTONYI ${ }^{2}$ \\ ${ }^{1}$ Facultad de Ciencias Naturales, Universidad Nacional de la Patagonia San Juan Bosco, Julio A. Roca 115, U9100AQC Trelew, \\ Chubut, Argentina.E-mail: anaruiztw@yahoo.com.ar \\ ${ }^{2}$ Centro Nacional Patagónico - CONICET, Bvrd. Almirante Brown 2825, 9120 Puerto Madryn, Chubut, Argentina. \\ E-mail: goszto@gmail.com
}

\begin{abstract}
The first two specimens of Regalecus glesne Ascanius, 1788, collected in the Argentine Sea, at Playa Unión beach, $43^{\circ}$ $18^{\prime} \mathrm{S}, 65^{\circ} 02^{\prime} \mathrm{W}$ are reported. Body measurements, meristic characters and morphological data are given. The most important differences with two other regalecid species, $R$. russelii Cuvier and $R$. kinoi Castro-Aguirre et al. 1991, from the Pacific coasts of Mexico, are considered. Also, a specimen caught at 43 03' S, 59 $14^{\prime} \mathrm{W}$, at $993 \mathrm{~m}$ depth, previously identified as Agrostichthys sp. is rediagnosed as Agrostichthys parkeri Benham, 1904. The distribution of $R$. glesne is extended to the Argentine Sea, adding a regalecid species to its fish fauna.
\end{abstract}

Key words: Regalecus glesne, Agrostichthys parkeri, Argentine Sea, report

\section{Introduction}

The regalecid fishes, grouped in two genera and four nominal species, are distributed worldwide in the seas except in the Polar Regions. In the south western Atlantic Agrostichthys sp. and Agrostichthys parkeri were reported by Gosztonyi (1981) and Figueroa \& Astarloa (1996) respectively, and more recently, Regalecus glesne and A. parkeri were found far beyond the Argentine Sea's eastern limits by Trunov \& Kukuev (2005). The descriptions of two specimens of $R$. glesne from Patagonian coastal waters, found stranded on Playa Unión beach at low tide by sport fishermen, during an eleven year span are presented. Also, the reexamination of another regalecid previously reported in the general area is included in order to formally add it to the Argentine fish fauna.

\section{Material examined}

Regalecus glesne Ascanius, 1788. Collected at Playa Unión beach, Chubut, Argentine Patagonia, 43 $18^{\prime}$ S; $65^{\circ} 02^{\prime}$ W. Specimen 1: female, $3805 \mathrm{~mm}$ total length, collected July 14, 1993 by Mr. Luis Ángel D'Antone; specimen 2: female, $4570 \mathrm{~mm}$ total length, collected at the same locality, June 15, 2004 by Mr. Julio Castillo. The latter specimen was preserved and catalogued at the Centro Nacional Patagónico (CONICET) Ichthyology Collection under accession number CNPICT 2004/40. Presently it is displayed for public exhibition at the Centro de Interpretación de la Biodiversidad Regional-AQUAVIDA in Playa Unión, Chubut, Argentina.

Agrostichthys parkeri Benham, 1904. Total length 2245 mm. Research Vessel "Shinkai Maru" 1978 Expedition to the Argentine Sea, Cruise 1. Collector Atila E. Gosztonyi, April 4, 1978. Position: 43 03' S; $58^{\circ} 57^{\prime} \mathrm{W}$, depth $993 \mathrm{~m}$. Preserved material: Head and end of tail, at the Centro Nacional Patagónico (CONICET) Ichthyology Collection, under accession number CNPICT 1978/13. 


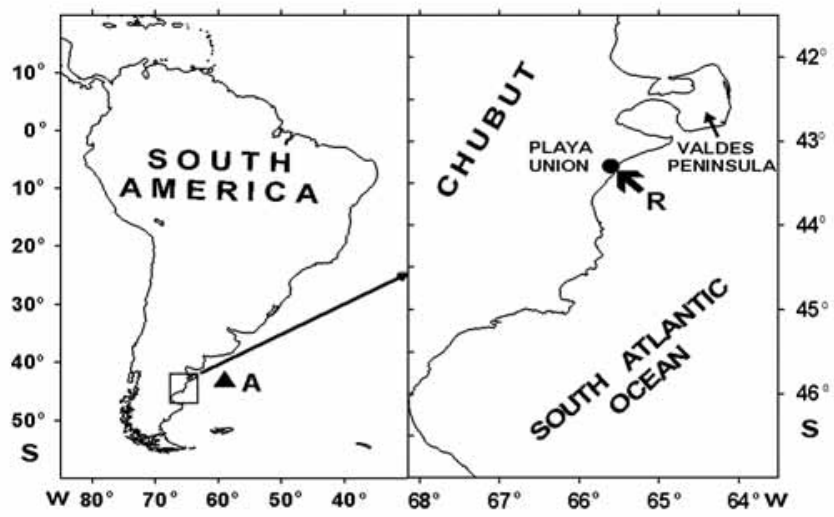

FIGURE 1. Record locations sites of Regalecid fishes in Argentine waters. R: Regalecus glesne, A: Agrostichthys parkeri.

\section{Results}

Morphometric and meristic data of both specimens of Regalecus glesne are presented in Table 1 and the collection location and views of the specimens are shown in figures 1 to 3, respectively.

The general body coloration was similar in both specimens being silvery bluish grey with a silvery light brown head, creamy ocular globes, a dark iris and clear pupils. The dorsal fin membranes were red, transparent at the basal part and surrounded the white rays. The pectorals were whitish grey.

In both specimens longitudinal dark bands could be seen along the sides. In specimen 1 the longitudinal bands, seven in number, extended along the whole body whereas in specimen 2 the bands, four in number, were restricted to the first third of each flank and the two remaining thirds had variably sized, irregularly distributed dark spots. Also, in the latter specimen, $1 \mathrm{~cm}$ wide and 6 to $7 \mathrm{~cm}$ long transverse dark bands extended regularly downwards from the dorsal mid-line on each flank. In specimen 1 the vertical stripes extended from the dorsal and ventral profiles toward the midline of the body to about $1 / 4$ of the flank.

The dorsal fin, beginning slightly in front of the orbits, exhibited nine, $500 \mathrm{~mm}$ long cephalic rays, followed by others of diminishing length to a minimum of about $100 \mathrm{~mm}$, at the end of the body. The pelvic fins (damaged in specimen 1) were longer than $35 \mathrm{~mm}$ and were supported by a single ray.

The skin, without scales, was covered by dermal tubercles with circular bases, 1 to $3 \mathrm{~mm}$ in diameter, either with or without a conical or blunt point, more visible and conspicuous at the ventral zone and lower sides of the body. The lateral line began behind the upper edge of the eyes, turned downward to the lower third of the side of the body ending at the caudal tip. Neither of the two specimens showed any pathological sign or external injury except for the accidentally broken jaw region in specimen 1.

The body cavity of both specimens showed a large, orange colored liver (386 mm long in specimen 2) and two white to pinkish non-turgid ovaries $(1000 \mathrm{~mm}$ long, with a maximum width of $290 \mathrm{~mm}$ and a triangular section in specimen 2) with only immature oocytes.

The stomach, $690 \mathrm{~mm}$ long, had numerous pyloric caeca in a $157 \mathrm{~mm}$ long mass, and was, just as the intestine, empty in both specimens and no internal parasites were observed.

According to the synoptic consideration of the forms referable to Regalecidae following Walters \& Fitch (1960), and those proposed by Castro-Aguirre et al. 1991, Salazar-Hermoso et al. 1999, and Balart et al. 2000, we could diagnose this specimen as belonging to $R$. glesne.

Regarding Agrostichthys parkeri, the preserved head and caudal region of a $2245 \mathrm{~mm}$ total length regalecid, which was diagnosed as Agrostichthys sp. by Gosztonyi (1981), were examined. It could be ascertained that this material belongs to Agrostichthys parkeri Benham, 1904 (Fig. 3B). Although this species was already mentioned for the Argentine waters by Figueroa and Astarloa (1996), the extreme paucity of its records at a worldwide level (McDowall \& Stewart 1999) deserves the formal record of this specimen. 


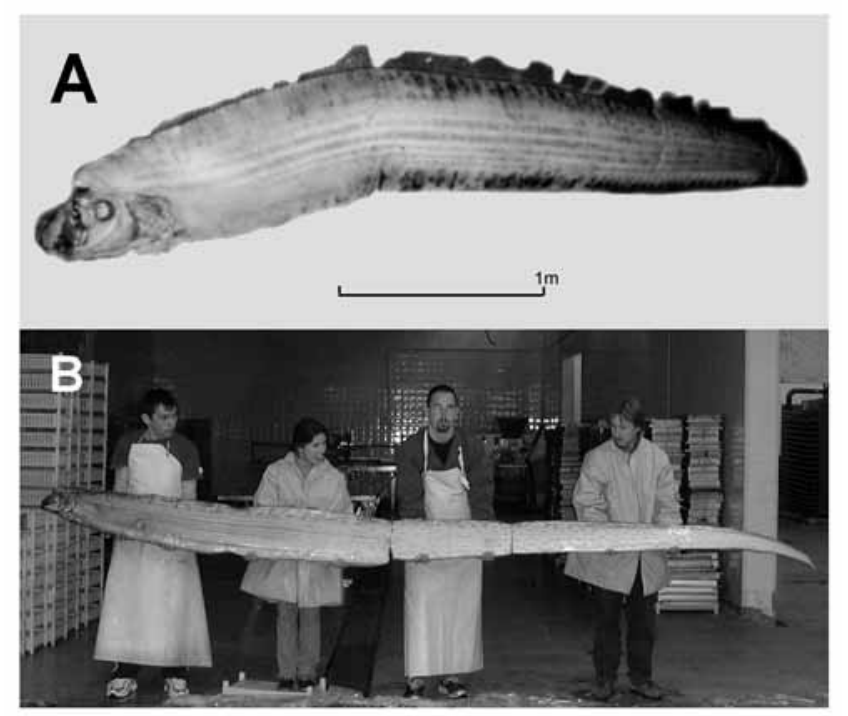

FIGURE 2. A: Regalecus glesne collected at Playa Unión (Patagonia, Argentina) on July 14, 1993. (The body is longer than apparent due to the angle in which the photograph was taken.) B: R. glesne, same locality, on June 15, 2004. The distance between people is approximately one metre.

TABLE 1. Measurements of Regalecus glesne specimens collected at Playa Unión, Patagonia, Argentina. Comparison with $R$. russelii y R. kinoi from Bahía de la Paz, Mexico, according to Salazar-Hermoso et al. (1999).* absolute value.

\begin{tabular}{|c|c|c|c|c|c|c|}
\hline \multirow[b]{3}{*}{ CHARACTER } & \multicolumn{4}{|c|}{$\begin{array}{l}\text { R. glesne } \\
\text { COLLECTION DATE }\end{array}$} & \multicolumn{2}{|c|}{$\begin{array}{l}\text { R. russelii R. kinoi } \\
\text { COLLECTION DATE }\end{array}$} \\
\hline & $\begin{array}{l}\text { July 14, } \\
1993\end{array}$ & $\begin{array}{l}\text { June } 15, \\
2004\end{array}$ & $1^{\mathrm{rst}}$ & $2^{\text {nd }}$ & $\begin{array}{l}\text { July } 16 \text {, } \\
1996\end{array}$ & $\begin{array}{l}\text { May 28, } \\
1991\end{array}$ \\
\hline & \multicolumn{6}{|c|}{$\%$ OF TOTAL LENGTH } \\
\hline TOTAL FROZEN WEIGHT (kg) & 45 & 43 & & & - & - \\
\hline TOTAL LENGTH (mm) & 3805 & 4570 & & & $5300^{*}$ & $4700^{*}$ \\
\hline PREANAL LENGTH & 1460 & 1450 & 38.37 & 31.73 & - & - \\
\hline MAXIMUM BODY DEPTH & 300 & 315 & 7.88 & 6.89 & - & 9.57 \\
\hline HEAD LENGTH & 200 & 191 & 5.26 & 4.18 & 6.13 & 7.94 \\
\hline HEAD DEPTH & - & 176 & - & 3.85 & 8.86 & 8.00 \\
\hline HORIZONTAL EYE DIAMETER & 35 & 39 & 0.92 & 0.85 & 0.98 & 1.00 \\
\hline SNOUT LENGTH & - & 80 & - & 1.75 & - & 3.51 \\
\hline PREORBITAL LENGTH & - & 54 & - & 1.18 & - & 1.32 \\
\hline PECTORAL FIN LENGTH & - & 88 & - & 1.93 & 2.07 & 3.36 \\
\hline PECTORAL FIN BASE & - & 21 & - & 0.46 & 1.18 & 1.15 \\
\hline NUMBER OF PECTORAL FIN RAYS & 15 & 12 & - & - & $12 *$ & $11 *$ \\
\hline NUMBER OF DORSAL FIN RAYS & - & 321 & - & - & - & $161^{*}$ \\
\hline MAXIMUM LENGTH OF DORSAL RAYS & 500 & 439 & 13.14 & 9.61 & - & - \\
\hline LENGTH OF THE FIRST GILL ARCH & - & 173 & - & 3.79 & 4.05 & 6.21 \\
\hline GILLRAKERS OF THE FIRST ARCH & - & $9+34$ & - & - & $49 *$ & $60 *$ \\
\hline
\end{tabular}




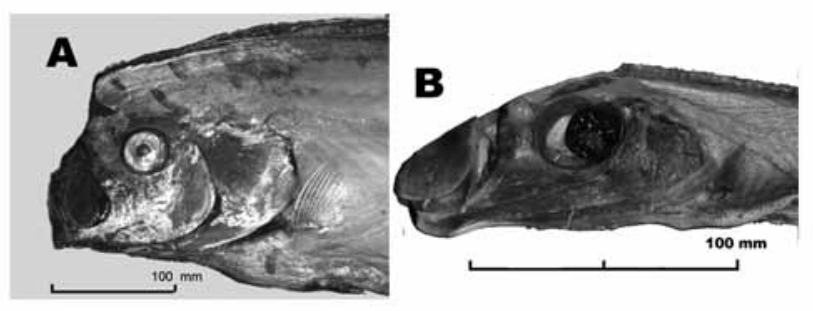

FIGURE 3. A: Head region of Regalecus glesne collected at Playa Unión (Patagonia, Argentina) on June 15, 2004. B: Head region of Agrostichthys parkeri collected in North Patagonian waters of the Argentine Sea, on April 4, 1978. Discussion

Both Regalecus specimens showed great similarity in anatomical and coloration characteristics, although the smaller one had a proportionally longer head, a larger eye and longer dorsal fin rays. Head and pectoral fin lengths of our specimens were proportionally shorter than those observed both in $R$. russelii Cuvier and $R$. kinoi Castro Aguirre et al. 1991, found at Bahía de la Paz, Mexico, by Salazar-Hermoso et al. (1999). Also the first gill arch of our second specimen was shorter than (3.79 vs $6.27 \% \mathrm{TL}$ ), and had less rakers than ( $9+34=43$ ), those reported for $R$. russelii and $R$. kinoi (49 and 60, respectively). The latter facts might lead us to consider our material as not conspecific with either one of the two nominal Pacific species of the genus.

On the other hand, comparisons with the specimens diagnosed by Trunov \& Kukuev (2005) as R. glesne and captured in South Western Atlantic waters, which were less than $2900 \mathrm{~mm}$ standard length, show coincidences in head length (5.26 vs 5.4-5.8\%TL), the preorbital length ( 28.3 vs $27.5-31.6 \%$ Head Length), the horizontal eye diameter (20.4 vs $20.1-21.0 \% \mathrm{HL})$ and differ only slightly in almost all other morphometrics.

In the body coloration of the South Atlantic material, Trunov and Kukuev noted the absence of transverse bands and spots in the flanks and associated this observation with a possible South Atlantic color pattern. The presence of spots in both specimens of the Argentine Sea and transverse bands on one of them curtails the arguments of the Russian researchers. In summary, it seems quite reasonable to assign our specimens to Regalecus glesne Ascanius, 1788.

There is uncertainty about the number of valid species of Regalecus, estimates of which range from one to four according to the different authors. Nelson (2006) considers the genus as monotypic, FishBase (Froese \& Pauly 2010) recognizes three valid species ( $R$. glesne Ascanius, $R$. russelii Cuvier and $R$. kinoi Castro-Aguirre et al.), whereas the CAS Catalog of Fishes (Eschmeyer 2010) recognizes $R$. pacificus Haast in addition to $R$. glesne, $R$. kinoi, and $R$. russelii. In a recent paper Schmitter-Soto (2008), examined recent literature about Regalecus and discussed the validity of certain citations in the Caribbean Sea, and considered $R$. kinoi as a synonym of $R$. russelii. Hopefully the forthcoming monograph of Regalecid fishes by Dr. Tyson Roberts (pers. comm.) will shed some light about this particular.

The discovery of $R$. glesne in Patagonian shelf waters, extends its distribution to the Argentine Sea and adds another Regalecid to the Argentine fish fauna in addition to Agrostichthys sp. (Gosztonyi 1981), which is rediagnosed herein as $A$. parkeri.

These discoveries and those made in the South Western Atlantic by Trunov \& Kukuev (2005), show that these species, together with the trachipterid Trachipterus jacksonensis Ramsay (found at $200 \mathrm{~m}$ off Río de Janeiro state and reported as T. nigrifrons Smith by Menezes [1971] and in Argentine Central Patagonia [Gosztonyi 1979], also cited as T. nigrifrons and the recent report by Trunov \& Kukuev [2005] of Trachipterus trachypterus Gmelin), are the known Trachipteroids of the South Western Atlantic Ocean. 


\section{Acknowledgments}

This study would not have been possible without the infrastructure of the fish processing plant of Interpesca S.A., Rawson, through the kindness of biologist R. Fondacaro. We thank students: P.D. Cochia, N. Bovcon, L. Mansur, M. Marcinkevicius and L. Martínez, for their help during laboratory works. Also, we appreciate the merit of the sport fishermen for their discoveries and the donation of the specimens. Finally we wish to express our thanks for the helpful suggestions made by the two anonymous referees.

\section{References}

ASCANIUS, P. (1788) Indsendte Beretning om Sild-Tusten. K. Dansk. Vidensk. Selsk. Skrift. Nye Samling, 3, 419-422.

BALART, E.F.; CASTRO-AGUIRRE, J.L. \& AMADOR-SILVA, E. (2000) A new record of the oarfish Regalecus kinoi (Lampridiformes: Regalecidae) in the Gulf of California, México. Oceánides, 14 (2),137-140.

BENHAM, W.B. (1904) An apparently new species of Regalecus (R. parkeri). New Zealand Institute Transfer, 36, 198200.

CASTRO-AGUIRRE, J.L., ARVIZU-MARTINEZ, J. \& ALARCÓN-GONZALEZ, C. (1991) Una especie nueva de Regalecus (Pisces: Lampridiformes) hallada en la Bahía de la Paz, Baja California Sur, México, con notas y observaciones taxonómícas y biogeográficas de la familia Regalecidae. Anales de la Escuela Nacional de Ciencias Biológicas, México, 34, 159-171.

ESCHMEYER, W. N. (ed.) Catalog of Fishes electronic version (19 February 2010). http://research.calacademy.org/ ichthyology/catalog/fishcatmain.asp

FIGUEROA, D.E. \& ASTARLOA, J.M. (1996) Occurrence of the oarfish Agrostichthys jacksoniensis (Regalecidae: Osteichthyes) in southernmost western atlantic. Neotropica, 42, 90.

FROESE, R. \& PAULY, D. Editors (2010) FishBase. World Wide Web electronic publication. www.fishbase.org version $(01 / 2010)$.

GOSZTONYI, A.E. (1979) On the presence of Trachipterus nigrifrons Smith, 1956, (Pisces, Lampridiformes) in the Western South Atlantic Ocean. Studies on Neotropical Fauna and Environment, 14, 153-155.

GOSZTONYI, A.E. (1981) Resultados de las investigaciones ictiológicas de la campaña I del B/I "Shinkai Maru" en el mar Argentino (10.04 09.05.1978).Contribuciones del Instituto Nacional de Investigación y Desarrollo Pesquero, Mar del Plata, 383, 254-266.

MCDOWALL, R.M. \& STEWART, A.L. (1999) Further specimens of Agrostichthys parkeri (Teleostei: Regalecidae) with natural history notes. In: Séret, B. \& Sire, J.-Y. (Eds.), Proceedings $5^{\text {th }}$ Indo Pacific Fish Conference, Nouméa, 1997. Society French Ichthyology, Paris, pp. 165-174.

MENEZES, N.A. (1971) The first record of Trachipterus in the Atlantic Coast of South America (Pisces, Trachipteridae). Papéis Avulsos de Zoologia, San Paulo, 23(23), 205-207.

NELSON, J.S. (2006) Fishes of the world. 4th edition. John Wiley \& Sons., Hoboken, NJ. 601pp.

SALAZAR-HERMOSO, F.; OCHOA-LÓPEZ, E. \& VILLAVICENCIO-GARAYZAR, C. (1999) Stranding records of the oarfish in and around Bahía de la Paz, México. California Fish and Game, 85 (2), 70- 74.

SCHMITTER-SOTO, J. J. (2008) The Oarfish, Regalecus glesne (Teleostei: Regalecidae), in the Western Caribbean. Caribbean Journal of Science, 44(1), 125-128.

TRUNOV, I. A. \& KUKUEV, E.I. (2005) New data on fishes of the family Trachipteridae and Regalecidae (Trachipteroidae) of the Argentine trench (Southwestern Atlantic). Journal of Ichthyology, 45 (3), 223-229.

WALTERS, V. \& FITCH, J.E. (1960) The families and genera of the Lampridiform (Allotriognathi) suborder Trachipteroidei. California Fish and Game. Conservation of wildlife through education, 45(4): 441- 451. 